\title{
OPINION MINING PEMUKA AGAMA DI INDONESIA TERHADAP CRYPTOCURRENCY MELALUI YOUTUBE
}

\author{
Dini Turipanam Alamanda, Yusuf Murtadlo Hidayat, Ikin solikin, Budi S \\ Purnomo
}

School of Post Graduates, Indonesia University of Education, Indonesia

Faculty of Economics, Garut University, Indonesia

Email:alamanda.dini.2017@gmail.com, yusuf.murtadlo@upi.edu, solikin65@gmail.co m, budi.purnomo@upi.edu

\begin{abstract}
Abstrak
Fenomena cryptocurrency sedang populer didunia termasuk di Indonesia. Meskipun Majelis Ulama Indonesia (MUI) dan Bank Indonesia telah menyampaikan sikapnya, namun nyatanya masyrakat masih mempertanyakan hukum cryptocurrency. Opini pemuka agama populer di Indonesia dianggap mampu memberikan pemahaman, namun kenyataan tidak semua pemuka agama mempunyai pandangan yang sama. Tujuan penelitian ini adalah untuk mengeksplorasi opini para pemuka agama populer di Indonesia mengenai hukum cryptocurrency. YouTube digunakan sebagai media untuk mencari sumber opini dari pemuka agama terpilih. Data selanjutnya dianalisis menggunakan opinion mining dan selanjutnya dipetakan polarisasinya. Hasil menunjukkan bahwa dari sejumlah pemuka agama populer, tidak semua mempunyai jejak digital di YouTube yang membahas mengenai cryptocurrency ataupun bitcoin. Secara umum, pemuka agama yang pernah membahas mengenai cryptocurrency terbagi dua, ada yang membolehkan dengan syarat tertentu dan ada yang mengharamkan secara tegas. Implikasi penelitian ini dapat digunakan sebagai bahan pertimbangan pemangku kebijakan dalam menyikapi posisi cryptocurrency ditengah-tengah penganut agama Islam terbesar di dunia.
\end{abstract}

Kata Kunci: cryptocurrency; bitcoin; opinion mining; pemuka agama; opinion leader

\section{Abstract}

The phenomenon of cryptocurrency is popular in the world, including in Indonesia. Even though the Indonesian Ulema Council (MUI) and Bank Indonesia have expressed their stance, in fact, the public still questions the cryptocurrency law. Opinions of popular religious leaders in Indonesia are considered capable of providing understanding, but the fact is that not all religious leaders have the same view. The purpose of this study is to explore the opinion of popular religious leaders in Indonesia regarding cryptocurrency law. YouTube is used as a medium to find sources of opinion from selected religious leaders. The data is then analyzed using opinion mining and then the polarization is mapped. The results show that of a number of popular religious 
leaders, not all have a digital footprint on YouTube that discusses cryptocurrency or bitcoin. In general, religious leaders who have discussed cryptocurrency are divided into two, some allow it under certain conditions and some expressly forbid it. The implications of this research can be used as consideration for policymakers in addressing the position of cryptocurrency in the midst of the world's largest Muslim adherents.

Keywords: cryptocurrency; bitcoin; opinion mining; religious leader; opinion leader

Received: 2021-10-20; Accepted: 2021-11-05; Published: 2021-11-20

\section{Pendahuluan}

Teknologi keuangan atau yang dikenal dengan fintech merupakan salah satu inovasi pada industri jasa keuangan (Yussof \& Al-Harthy, 2018). Diantara fintech lainnya, cryptocurrency adalah yang paling kontroversial (Yussof \& Al-Harthy, 2018; Schwab-Pomerantz, 2019). Cryptocurrency memungkinkan masyarakat untuk melakukan transaksi, mining (penambangan), investasi, dan trading (Widyastuti \& Hermanto, 2021). Popularitas cryptocurrency meningkat saat masyarakat membutuhkan kepastian yang tidak mampu dilakukan oleh ekosistem keuangan setelah krisis keuangan 2008 (Rejeb, Rejeb, \& Keogh, 2021).

Indonesia merupakan negara dengan jumlah penduduk muslim terbanyak di dunia. Dalam merespon cryptocurrency, masyarakat Indonesia menyambut baik dengan peningkatan pengguna yang cukup signifikan dari tahun ke tahun (Saputra, 2018). Namun, berbeda dengan pemerintah dalam hal ini Bank Indonesia yang sejak awal tidak mengakui dan melarang transaksi menggunakan bitcoin (salah satu mata uang di pasar cryptocurrency). Dalam perkembangannya, Bank Indonesia terus menyatakan bahwa perekonomian Indonesia bisa terancam dari kehadiran cryptocurrency (Kontan, 2021). Penyataan tersebut sejalan dengan temuan Noh \& Bakar (2020) bahwa dengan segala inovasi cryptocurrency, bahaya kerugiaan yang bukan hanya akibat system harus diwaspadai.

Berbeda dengan Bank Indonesia, Majelis Ulama Indonesia (MUI) memberikan pandangan mengenai cryptocurrency dari sisi syariat Islam. Terdapat dua hukum yang diberlakukan yaitu mubah untuk aktivitas alat tukar dan haram untuk inversitasi (Tektona \& Safilia, 2020). Polas et al. (2020) menyimpulkan bahwa cryptocurrency dan token bersifat Halal, namun perlu disaring mana yang sesuai dengan syariat dan yang tidak sesuai syariat Islam.

Pernyataan Bank Indonesia dan MUI ternyata masih belum memuaskan masyarakat muslim di Indonesia. Referensi lain yang dibutuhkan adalah pandangan pemuka agama (Hamin, 2020). Pemuka agama yang kredibel, memahami konteks lokal dan mempunyai jejaring yang luas dan akses ke berbagai sumber kekuatan masyarakat berdampak signifikan pada persepsi masyarakat mengenai hukum sesuatu hal (Samuel \& Pandey, 
2018). Presiden Joko Widodo berpendapat bahwa pemuka agama berpengaruh pada aksi masyarakat muslim Indonesia (Sindonews, 2021). Lembaga Survei Indonesia (2018) mengemukakan bahwa terdapat lima pemuka agama paling berpengaruh di Indonesia. Ustad Abdul Somad merupakan pemuka agama yang paling dikenal dan disukai, disusul oleh Ustad Yusuf Mansur, Ustad Arifin Ilham, Ustad Aa Gym dan Habib Rizieq Shihab (Lembaga Survei Indonesia, 2018). Adapun kriteria yang dimunculkan adalah tingkat pengenalan tokoh (40\%), tingkat kesukaan terhadap ulama (50\%) dan kemampuan mempengaruhi (15\%). Sedangkan versi The Muslim 500, pemuka agama di Indonesia paling berpengaruh dan yang masuk didalamnya antara lain Abdullah Gymnastiar (Aa Gym) dan Quraish Shihab (Kompas, 2020).

Berdasarkan hasil pencarian, pemuka-pemuka agama yang disebutkan sebelumnya mempunyai beberapa platform media sosial untuk aktivitas penyebaran ilmu agama, hobi, bisnis, maupun kehidupan sehari-hari. Platform media sosial versi GlobalStats (2021) memunculkan data bahwa Facebook adalah yang paling banyak diakses dengan $61.32 \%$, YouTube $(24.49 \%)$, Instagram (3.48\%), Twitter $(3.11 \%)$, Pinterest $(2.02 \%)$ dan Tumblr $(0.37 \%)$ yang perkembangannya disajikan pada Gambar 1.

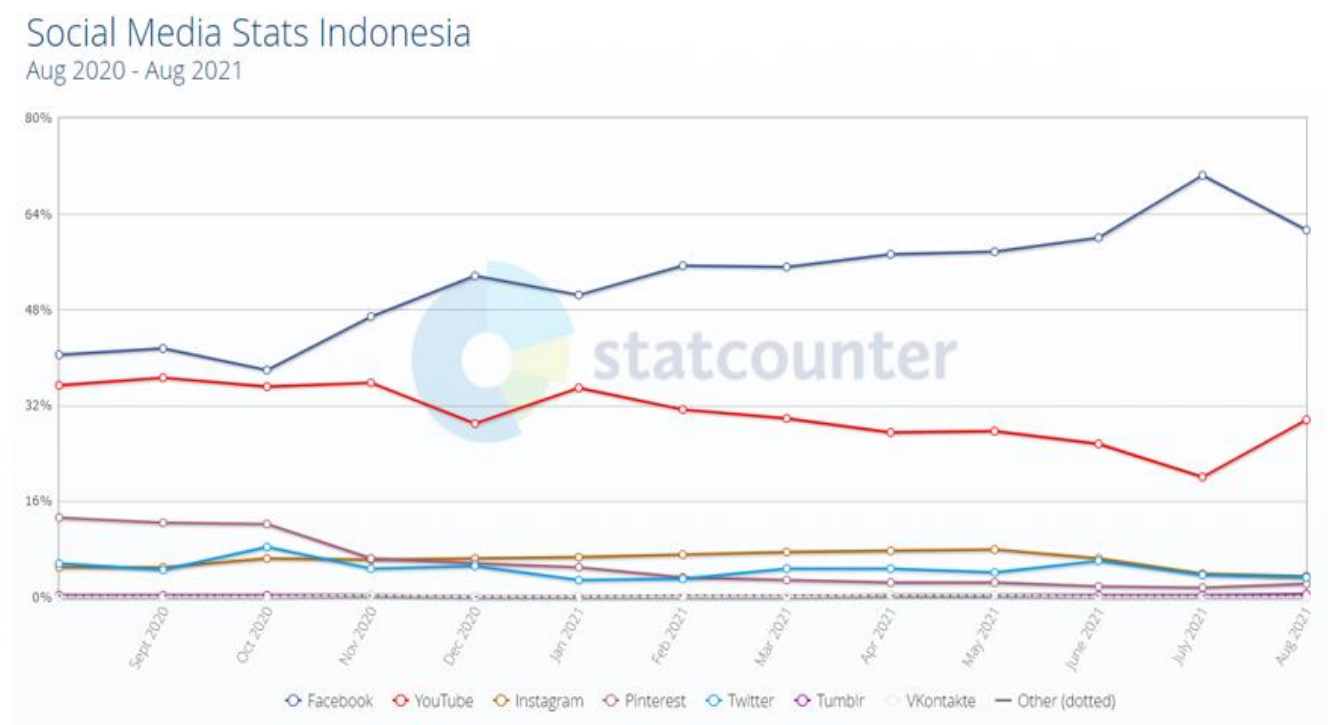

Gambar 1

\section{Statistika Media Sosial di Indonesia Periode Agustus 2020 - Agustus 2021 (GlobalStats, 2021)}

Adapun jenis-jenis platform yang paling banyak digunakan oleh pemuka agama popular di Indonesia adalah Instagram, diikuti oleh Facebook, Youtube dan Twitter, sedangkan Pinterest dan Tumblr tidak ditemukan akun resmi. Daftar platform yang digunakan oleh pemuka agama popular di Indonesia disajikan pada Tabel 1. 
Tabel 1

Daftar Platform Yang Digunakan Oleh Pemuka Agama Indonesia

\begin{tabular}{lllll}
\hline \multirow{2}{*}{ Nama } & \multicolumn{4}{l}{ Jenis Platform Media Sosial } \\
& Facebook & YouTube & Instagram & Twitter \\
\cline { 2 - 5 } & & $\sqrt{ }$ & $\sqrt{ }$ & \\
\hline Ustad Abdul Somad (UAS) & & $\sqrt{ }$ & $\sqrt{ }$ & \\
\hline Ustad Yusuf Mansur (UYM) & $\sqrt{ }$ & $\sqrt{ }$ & \\
\hline Ustad Arifin Ilham (UAI) & $\sqrt{ }$ & & $\sqrt{ }$ & \\
\hline Ustad Aa Gym (Aa Gym) & $\sqrt{ }$ & $\sqrt{ }$ & $\sqrt{ }$ & \\
\hline
\end{tabular}

Habib Rizieq Shihab (HRS)

$\begin{array}{llll}\text { Quraish Shihab (QS) } & \sqrt{ } & \sqrt{ } & \sqrt{ }\end{array}$

Sumber: Hasil Observasi Penulis (2021)

Setiap media sosial mempunyai karakteristik yang berbeda, Instagram memberikan layanan kepada pengguna untuk bisa memposting foto/ video singkat pada feed maupun story/ IGTV/ atau reels. YouTube menawarkan semua jenis video dengan layanan durasi yang lebih lama daripada Instagram. Pemilihan YouTube dan Instagram sebagai media untuk menyampaikan pengaruh oleh pemuka agama popular di Indonesia relevan dengan temuan Sokolova \& Kefi (2020) yang menyatakan bahwa YouTube dan Instagram adalah media sosial yang banyak digunakan influencer.

Observasi mengenai konten masing-masing pemuka agama perlu digali berkaitan dengan tema hukum bitcoin yang menjadi inti dari penelitian ini. Konten ceramah pemuka agama popular di atas nyatanya banyak diunggah oleh banyak akun bebas, bukan dari akun resmi mereka. Selain itu banyak konten ceramah yang tidak diunngah oleh akun resmi para pemuka tersebut, sehingga dalam pencariannya data, penggunaan kata kunci jauh lebih penting dibandingkan dengan mengobservasi akun resmi. Diantara platform media sosial, YouTube dianggap yang paling efektif untuk aktivitas dakwah oleh para pemuka agama (Sulaeman, Fazri, \& Fairus, 2020).

Berkaitan dengan cryptocurrency, bitcoin atau mata uang digital, opini para pemuka tentulah akan sangat berpengaruh pada persepsi masyarakat yang mengikuti dan menyukainya. Sehingga perkembangan cryptocurrency dan blockchain tidak hanya bergantung pada kemajuan teknologi namun juga kondisi sosial ekonomi, tingkat pembangunan, hubungan internasional, hambatan politik dan hukum dan lain-lain di suatu negara (Sichinava, 2019). Dengan kata lain, keberlangsungan cryptocurrency di Indonesia, selain dari keputusan Bank Indonesia juga bergantung pada opini dari para 
pemuka agama yang diunggah pada media yang bisa diakses oleh banyak pengikutinya di Indonesia.

Penelitian mengenai bagaimana cara memotret opini tokoh populer sudah banyak dikaji dalam penelitian sosial. Penggunaan YouTube untuk opinion mining lebih baik karena memungkinkan untuk mengeksploitasi informasi konteks, mungkin juga informasi multi-modal, yang tidak tersedia dalam pada Twitter (Severyn, Moschitti, Uryupina, Plank, \& Filippova, 2014). Berdasarkan fenomena tersebut, tujuan penelitian ini adalah untuk mengeksplorasi opini para pemuka agama populer di Indonesia mengenai hukum cryptocurrency yang diunggah pada YouTube.

\section{Metode Penelitian}

\section{Karakteristik dan tahapan penelitian}

Penelitian ini bersifat kualitatif dengan pendekatan eksploratif karena bertujuan untuk menggali informasi lebih banyak mengenai opini pemuka agama terhadap hukum bitcoin di Indonesia. Data mining digunakan. Tahapan opinion mining pada penelitian ini adalah

1) Melakukan pencarian pemuka agama terkemuka di Indonesia yang mempunyai konten YouTube mengenai cryptocurrency, bitcoin, block chain, dan mata uang digital.

2) Jika tidak ditemukan, maka alternatifnya adalah mencari tokoh berpengaruh yang membahas cryptocurrency, bitcoin, block chain, dan mata uang digital.

3) Penentuan pemuka agama yang terpilih adalah berdasarkan profil, popularitas dan jumlah views pada saat membahas cryptocurrency, bitcoin, block chain, dan mata uang digital.

4) Selanjutnya adalah tahapan pengambilan opini (scraping) isi dakwah pemuka agama tersebut lalu ditranskrip.

5) Menganalisis opini pemuka agama dengan reduksi menggunakan teknik komparasi hukum Islam terhadap cryptocurrency.

6) Menyajikan data menggunakan mind map dengan bantuan software mindjet mind manajer 2021.

7) Menyimpulkan temuan lalu lalu melakukan triangulasi teori dengan membandingkan temuan dengan teori-teori atau hasil penelitian lainnya mengenai hukum cryptocurrency.

\section{Pemilihan target dan sumber opini}

Target opini mengacu pada orang, objek, fitur, peristiwa atau topik tentang opini yang diungkapkan. Karena identifikasi target opini adalah fitur penting dari opinion mining, tinjauan ekstensif tentang pendekatan yang terkait dengan ekstraksi target opini diperlukan (Khan, Baharudin, Khan, \& Ullah, 2014). Pemilik opini atau sumber opini adalah orang atau media yang menyampaikan opini dan secara otentik 
memiliki kekuatan, penerapan dan klasifikasi opini, karena kualitas dan keandalan suatu opini sangat bergantung pada sumber opini tersebut.

Berdasarkan temuan Lembaga Survei Indonesia (2018) dan Kompas (2020), profil pemuka agama terpopuler di Indonesia terdiri dari Ustad Yusuf Mansur (UYM), Ustad Arifin Ilham (UAI), Ustad Aa Gym (Aa Gym), Habib Rizieq Shihab (HRS) dan Quraish Shihab (QS). Dari Tabel 1 dapat dilihat bahwa HRS tidak memiliki akun media sosial dikarenakan akun Instagramnya @habib.rizieq mengalami pemblokiran dan diganti dengan @habibrizieqsyihab pada tahun 2016 (Jawa Pos, 2016), diikuti dengan pemblokiran akun Twitter@syihabrizieq pada awal tahun 2017. Namun, hasil observasi, akun @ habibrizieqsyihab juga sudah tidak ada.

Penelitian ini akan mengambil opini pemuka agama dari media YouTube, dari Tabel 1, dapat diketahui bahwa hanya UAS, UYM, Aa Gym dan QS yang mempunyai chanel YouTube. Setelah dilakukan observasi, dari 4 pemuka agama tersebut, hanya UAS dan QS yang pernah membahas mengenai cryptocurrency, bitcoin, block chain, dan mata uang digital dengan rincian disajikan pada Tabel 2.

\section{Tabel 2}

Riwayat dakwah pemuka agama melalui YouTube

\begin{tabular}{|c|c|c|c|c|}
\hline Inisial & Profil YouTube & $\begin{array}{l}\text { Juduk unggahan pada } \\
\text { YouTube }\end{array}$ & $\begin{array}{l}\text { Akun } \\
\text { penggunggah }\end{array}$ & $\begin{array}{l}\text { Tanggal } \\
\text { unggah }\end{array}$ \\
\hline \multirow[t]{4}{*}{ UAS } & $\begin{array}{l}\text { Ustadz Abdul } \\
\text { Somad Official } \\
(2,19 \quad \text { M }\end{array}$ & $\begin{array}{l}\text { Hukum } \text { Urusniaga } \\
\text { Ustadz }\end{array}$ & $\begin{array}{l}\text { Abu Amzar } \\
\text { Channel } \\
\text { (40 K penonton) }\end{array}$ & 7 Maret 2018 \\
\hline & & $\begin{array}{l}\text { Hukum Bitcoin atau } \\
\text { Cryptocurrency dalam agama } \\
\left(80^{\prime} 10^{\prime \prime}\right)\end{array}$ & $\begin{array}{l}\text { Dakwah Singkat } \\
\text { Padat } \\
\text { (295 K } \\
\text { penonton) }\end{array}$ & 1 Februari 2021 \\
\hline & & $\begin{array}{l}\text { Abdul Somad.Hukum jual } \\
\text { beli cryptocurrency } \\
\text { indodax }\left(4^{\prime} 05^{\prime}\right)\end{array}$ & $\begin{array}{l}\text { Suparman Fatwa } \\
\text { ( } 22 \mathrm{~K} \text { penonton) }\end{array}$ & 9 Februari 2021 \\
\hline & & $\begin{array}{l}\text { Bagaimana Hukum Investasi } \\
\text { Digital Coin Ustadz?| Ustadz } \\
\text { Abdul Somad, Lc., MA } \\
\left(8^{\prime} 08^{\prime},\right)\end{array}$ & $\begin{array}{l}\text { Ustadz Abdul } \\
\text { Somad Official } \\
(29,4 \quad \mathrm{~K} \\
\text { penonton) }\end{array}$ & 13 Maret 2021 \\
\hline
\end{tabular}


Dini Turipanam Alamanda, Yusuf Murtadlo Hidayat, Ikin solikin, Budi S Purnomo

\begin{tabular}{|c|c|c|c|c|}
\hline Inisial & Profil YouTube & $\begin{array}{l}\text { Juduk unggahan pada } \\
\text { YouTube }\end{array}$ & $\begin{array}{l}\text { Akun } \\
\text { penggunggah }\end{array}$ & $\begin{array}{l}\text { Tanggal } \\
\text { unggah }\end{array}$ \\
\hline & & $\begin{array}{l}\text { Hukum Trading!!Bitcoin } \\
\text { Cryptocurrency!!Ustadz } \\
\text { Abdul Somad (3'57',) }\end{array}$ & $\begin{array}{l}\text { Amjad TV } \\
\text { (12 K penonton) }\end{array}$ & 13 Maret 2021 \\
\hline & & $\begin{array}{l}\text { Hukum Cryptocurrecy dalam } \\
\text { islam UAS - Ustadz Abdul } \\
\left.\text { Somad Lc. ( } 8{ }^{\prime} 07^{\prime} '\right)\end{array}$ & $\begin{array}{l}\text { Hukum Islam } \\
\text { Populer } \\
\text { (2,8 K penonton) }\end{array}$ & 14 Mei 2021 \\
\hline QS & $\begin{array}{l}\text { Quraish Shihab } \\
\text { (70, } 3 \quad \mathrm{~K} \\
\text { pengikut) }\end{array}$ & $\begin{array}{l}\text { Hukum Islam Soal Uang } \\
\text { Elektronik, KB dan Sebar } \\
\text { Hoaks | Shihab \& Shihab } \\
\text { (36'02") }\end{array}$ & $\begin{array}{l}\text { Najwa Shihab } \\
\text { (275 K } \\
\text { penonton) }\end{array}$ & 14 Oktober 2019 \\
\hline
\end{tabular}

Sumber: Observasi penulis (2021).

\section{Klasifikasi Opini}

Turney (2002) menyatakan bahwa untuk setiap dokumen input $\mathrm{d}$ memiliki istilah $\mathrm{T}$ di mana setiap istilah $\mathrm{t}$ milik $\mathrm{T}$, jika polaritasnya adalah $(1,0,1)$ di mana 1 mewakili polaritas positif, 0 mewakili polaritas netral dan 1 mewakili polaritas negatif, maka jika jumlah polaritas semua suku lebih besar dari 0, dokumen dianggap positif; jika jumlah polaritas semua suku kurang dari 0 , maka dokumen tersebut negatif; dan jika jumlahnya sama dengan 0 , maka dokumen tersebut dianggap netral.

\section{Hasil dan Pembahasan}

\section{Hukum cryptocurrency menurut UAS}

Dalam dakwahnya, UAS tidak membuat tema khusus mengenai cryptocurrency, tetapi dalam konteks merespon pertanyaan jamaah. Dari enam video YouTube, ternyata sumbernya hanya dari tiga kegiatan tanya-jawab ceramah. Video jenis pertama adalah yang diunggah oleh (Channel, n.d.), jenis video kedua adalah yang diunggah oleh Dakwah Singkat Padat (2021); Hukum Islam Populer, (2021); dan Ustadz Abdul Somad Official (2021). Sedangkan video ketiga adalah yang diunggah oleh chanel Suparman Fatwa (2021) dan Amjad TV (2021). Adapun situasi kegiatan tanya-jawab bersama UAS digambarkan pada Tabel 3. 
Tabel 3

Kegiatan tanya-jawab cryptocurrency

\begin{tabular}{lll}
\hline Video ke- & Bentuk Pertanyaan & Lokasi Unggah \\
\hline 1 & $\begin{array}{l}\text { Apa hukum berurusniaga cryptocurrecy } \\
\text { bitcoin dalam Islam? }\end{array}$ & Abu Amzar Channel (2018) \\
\hline 2 & $\begin{array}{l}\text { Bagaimana hukum berinvesitasi digital } \\
\text { coin, lebih spesifiknya lagi EDCCash? }\end{array}$ & 1) Dakwah Singkat Padat (2021) \\
& & (2021) \\
& & 3) Hukum Islam Populer (2021) \\
\hline 3 & $\begin{array}{ll}\text { Video Tuan Guru Abdul Somad tentang } \\
\text { hukum Bitcoin atau edinarcoin atau mata }\end{array}$ & \\
& uang digital saat ini kami masyarakat & 2) Amjad TV (2021) \\
Indragiri Hulu hampir merata bergabung & \\
dalam member edinarcoin bahkan ada & \\
beberapa postingan mereka di Facebook & \\
yang menjadikan video Ustad Somad & \\
sebagai dasar dibolehkannya edinarpay \\
atau bitcoin sementara edinarcoin ini \\
merupakan salah satu bisnis jual beli mata \\
$\begin{array}{l}\text { uang digital yang dibuat oleh sekelompok } \\
\text { komunitas? }\end{array}$
\end{tabular}

Dalam tiga video tersebut, satu video menampilkan UAS belum menyebutkan hukum yang jelas, hanya menyampaikan sifat dari perdagangan dan meminta jamaah untuk menanyakan pada ahli cryptocurreny (Abu Amzar Channel, 2018|1'10-1'20"). Sedangkan pada dua jenis video, UAS sudah mengungkapkan hukum cryptocurrency. UAS memberikan jawaban berdasarkan hasil kesepakatan pertemuan ulama di Universitas Darussalam Gontor Ponorogo. Hukum cryptocurrency terbagi dua, yaitu boleh sebagai alat tukar dan sebaiknya dihindari jika digunakan untuk investasi (Dakwah Singkat Padat, 2021|5'10' - 5'58', Ustadz Abdul Somad Official, 2021| 5'00" - 5'47"; Suparman Fatwa, 2021| 2’04'’-2’20'”; Hukum Islam Populer, 2021| 4'49" - 5'37"; Amjad TV, 2021|1'50"-2'00").

Hal tersebut menunjukkan bahwa pendapat UAS berubah dari netral menjadi negatif terhadap sifat cryptocurrency. Perubahan sikap UAS bisa dikarenakan pada perkembangan diskusi para ulama Indonesia mengenai cryptocurrency, bitcoin, block chain, dan mata uang digital. Pendapat netral UAS berasal dari unggahan video pada tanggal 7 Maret 2018 (Abu Amzar Channel, 2018) dan hampir dua tahun kemudian, unggahan mengenai cryptocurrency, bitcoin, block chain, dan mata uang digital viral kembali (Dakwah Singkat Padat, 2021; Ustadz Abdul Somad Official, 2021; Suparman Fatwa, 2021; Hukum Islam Populer, 2021; Amjad TV, 2021). UAS juga menyebutkan bahwa cryptocurrency mempunyai sifat seperti uang kertas dan bisa digunakan sebagai alat tukar. 
“.... beberapa pakar ekonomi Islam membahas tentang bitcoin. Maka hasilnya kalau dia dipakai sebagai alat tukar sama seperti uang kertas, boleh sebagai alat tukar. Untuk beli, cash, boleh"

(Ustadz Abdul Somad Official, 2021| 5'00" - 5'20).

Pandangan tersebut sejalan dengan MUI bahwa meskipun bitcoin bukan mata uang resmi, namun bisa digunakan sebagai alat tukar dengan catatan bahwa mata uang yang dipertukarkan sejenis, memiliki nilai yang sama dan tunai (Tektona \& Safilia, 2020). Lain halnya dengan temuan Yussof \& Al-Harthy (2018) yang membahas bitcoin di Malaysia. Menurutnya, bitcoin tidak didukung oleh pemerintah mana pun sebagai alat pembayaran yang sah, dan dengan demikian gagal berfungsi sebagai uang. Sebagai regulator, Bank Indonesia menegaskan bahwa cryptocurrency tidak diakui sebagai alat pembayaran sah berdasarkan Undang-Undang Dasar (UUD), dan melarang seluruh keuangan yang bermintra dengan Bank Indonesia untuk tidak memfasilitasi transaksi bitcoin dan jenis cryptocurrency lainnya (Kontan, 2021). Bank Indonesia menekankan pada resiko sistem pembayaran dan pengelolaan, aliran modal keluar asing, resiko stabilitas sistem keuangan, resiko pelanggaran seperti money laundry dan resiko data pelanggan dakam aktivitas cryptocurrency.

Adapun penjelasan UAS mengapa investasi cryptocurrency sebaiknya dihindari adalah 1) sulit diukur; 2) tidak konsisten dan sangat fluktuatif; 3) tidak terbuka mengenai detail investasinya dan 4) tidak diketahui sampai kapan nilai intrinsiknya. Dalam menjelaskan poin pertama, UAS memberikan gambaran mengenai uang dolar yang bisa diukur dibandingkan dengan bitcoin.

"Tapi kalau sebagai investasi, dihindari. Jangan pakai untuk investasi...... Pertama, tidak bisa diukur nilai tukarnya. kalau dolar, ril, bisa diukur. Bitcoin ini tidak terukur" (Ustadz Abdul Somad Official, 2021|5'21'" - 5'31).

Untuk poin kedua, UAS menjelaskan konsisten nilai yang dikaitkan dengan waktu, "..... Tidak ada jaminan dia konsisten hari ini berapa bulan depan berapa" (Ustadz Abdul Somad Official, 2021| 5'31" - 5'40). Poin ketiga yaitu tidak terbuka mengenai detail investasinya, UAS menghubungkan dengan lokasi investasi yang jelas sehingga sifatnya ghoror. Poin terakhir mengenai tidak diketahui sampai kapan nilai intrinsiknya, UAS menghubungkan dengan logam mulia. UAS juga memberikan penjelasan mengenai perkembangan transaksi di dunia, dimulai dari proses barter, sejarah beredarnya dinar, kemunculan uang kertas, dan terakhir mengenai uang digital (Dakwah Singkat Padat, 2021; Ustadz Abdul Somad Official, 2021; Hukum Islam Populer, 2021).

\section{Hukum cryptocurrency menurut QS}

Penjelasan mengenai cryptocurrency oleh QS tidak disampaikan dengan jelas. Hal tersebut dikarenakan pertanyaan yang disampaikan oleh penanya tidak disecara langsung namun melalui platform lain yang dibacakan oleh pembawa acara yaitu Najwa Shihab (Shihab, 2019). Adapun pertanyaan tersebut adalah 
"Penggunaan virtual money, uang virtual, apakah boleh dalam Islam? "(Shihab \& Shihab, 2021|26'37''-26'50'').

Adapun jawaban QS mengenai virtual money adalah boleh, dengan catatan tidak ada penipuan didalamnya dan suka sama suka.

"Boleh tidak ada masalah, selama kegiatan ekonominya jelas, tiada ada penipuan, apalagi sama-sama suka, maka tidak ada masalah. Biasanya itu tidak jelas, biasanya ada hal-hal mengandung penipuan, maka agama melarangnya. Yang dilarang adalah penipuannya bukan kemajuan teknologinya. Sekarang itu ada upaya, daripada bawa uang ke masjid bawa e-money. Itu kan teknologi. Ada banyak yang tidak ada di jaman nabi, sekarang ada. Ketetapan hukum itu dikaitkan dengan sebab larangannya, harus menjadi pertimbangan ketika berbicara ada pada jaman nabi atau tidak, dengan cara mengetahui maksud larangan tersebut. “(Shihab \& Shihab, 2021| 26'54”-30'14”').

Terdapat beberapa catatan dari jawaban QS yang bisa diterapkan pada hukum cryptocurrency, antara lain:

1) teknologi boleh diikuti, termasuk dari teknologi pembayaran;

2) larangan dalam transaksi keuangan adalah jika terdapat penipuan;

3) larangan dalam transaksi keuangan harus diikuti dengan argumen mengenai larangan tersebut.

Pendapat QS selaras dengan kelompok pertama yang menjadi temuan Yussof \& Al-Harthy (2018), yaitu tidak ada larangan dalam Islam jika syarat-syarat terpenuhi. Dalam polaritas opini, pendapat QS terhadap perkembangan keuangan mewakili polaritas positif atau 2 (Turney, 2002).

\section{Pendapat tokoh lain yang mungkin berpengaruh}

Selain UAS dan QS, pada perkembangannya beberapa pemuka agama lain juga memberikan argumennya terkait dengan cryptocurrency. Yenny Wahid selaku Founder Islamic Law Firm berpendapat bahwa sampai hari ini, hukum mata uang kripto belum jelas, Sebagian mengatakan halal, lainnya meyakini haram. Pendapat haram dilihat dari volatilitasnya yang tinggi sehingga membahayakan pemilik modal sedangkan unsur gharar dalam cryptocurrency belum cukup bukti untuk dikatakan haram, karena pada faktanya tidak terdapat potongan biaya saat transaksi (Wahid, 2021).

Berbeda dengan ustad Erwandi Tarmizi, bitcoin tidak ada fisiknya dan tidak jelas sehingga haram hukumnya (Tarmizi, 2018). Dan hukum bitcoin menurut Ustadz Buya Yahya adalah haram karena sumbernya tidak jelas, hanya angka-angka dan tidak ada wujudnya serta tida ada pelindung dari negara (Yahya, 2018).

\section{Kesimpulan}

Dari hasil eksplorasi, dapat disimpulkan bahwa terdapat pemuka agama yang menyatakan jelas bahwa cryptocurrency termasuk bitcoin didalamnya hukumnya boleh dengan catatan seperti Ustad Abdul Shomad, Quraish Shihab dan Yenni Wahid, adajuga yang dengan tegas menyatakan hukumnya haram seperti yang disampaikan Ustad Erwandi Tarmizi dan Buya Yahya. Adapun yang dimaksud boleh oleh Ustad Abdul 
Dini Turipanam Alamanda, Yusuf Murtadlo Hidayat, Ikin solikin, Budi S Purnomo

Shomad terkait dengan jenis, yaitu jika digunakan untuk sebagai alat transaksi bukan untuk investasi. Begitupula dengan Quraish Shihab yang menyatakan boleh pada mata uang digital tidak spesifik mengenai cryptocurrency ataupun bitcoin

\section{BIBLIOGRAFI}

Abu Amzar Channel. (2018). Hukum Urusniaga Bitcoin | Ustadz Abdul Somad. Indonesia. Google Scholar

Amjad TV. (2021). Hukum Trading!!BITCOIN Cryptocurrency!!Ustadz Abdul Somad. Indonesia. Google Scholar

Channel, Abu Amzar. (n.d.). Hukum Urusniaga Bitcoin. Retrieved from https://www.youtube.com/watch?v=9hZQwHXTbCw\&t=11s Google Scholar

Dakwah Singkat Padat. (2021). Hukum Bitcoin atau Cryptocurrency dalam agama.

GlobalStats. (2021). Social Media Stats Indonesia Aug 2020 - Aug 2021. Google Scholar

Hamin, Dewi Indrayani. (2020). Crypto Currensi Dan Pandangan Legalitas Menurut Islam: Sebuah Literature Review. Jurnal Imiah Manajemen Dan Bisnis, 3(2), 127139. Google Scholar

Hukum Islam Populer. (2021). Hukum Cryptocurrecy dalam islam UAS - Ustadz Abdul Somad Lc. Indonesia. Google Scholar

Khan, Khairullah, Baharudin, Baharum, Khan, Aurnagzeb, \& Ullah, Ashraf. (2014). Mining opinion components from unstructured reviews: A review. Journal of King Saud University - Computer and Information Sciences, 26(3), 258-275. https://doi.org/https://doi.org/10.1016/j.jksuci.2014.03.009 Google Scholar

Kompas. (2020, September). 22 Tokoh Indonesia di Daftar 500 Muslim Paling Berpengaruh Dunia 2021. Www.Kompas.Com. Google Scholar

Kontan. (2021). Bank Indonesia mengingatkan lima risiko besar maraknya perdagangan cryptocurrency. Nasional.Kontan.Co.Id. Google Scholar

Lembaga Survei Indonesia. (2018). Inilah 5 Ulama Paling Berpengaruh di Indonesia. Kabar24.Bisnis. Com. Google Scholar

Noh, Mohd Shahid Mohd, \& Bakar, Mohamed Syakir Abu. (2020). CryptocurrencyasAMainCurrency:A Maqasidic Approach. Al-Uqud: Journal of Islamic Economics, 4(1), 115-132. https://doi.org/DOI:10.26740/aluqud.v4n1.p115-132 Google Scholar

Polas, Mohammad Rashed Hasan, Muhibbullah, Md, \& Bhattacharjee, Amitab. (2020). Is Bitcoin Halal or Haram In The Islamic Banking And Finance? An Overview. 
Opinion Mining Pemuka Agama di Indonesia terhadap Cryptocurrency Melalui Youtube

Journal of Economics, Business and Market Research (JEBMR), 1(2), 96-104. Google Scholar

Rejeb, Abderahman, Rejeb, Karim, \& Keogh, John G. (2021). Cryptocurrencies in Modern Finance: A Literature Review. Etikonomi, 20(1), 93 - 118. https://doi.org/https://doi.org/10.15408/etk.v20i1.16911. Google Scholar

Samuel, P., \& Pandey, S. (2018). Life satisfaction and altruism among religious leaders. International Journal of Indian Psychology, 6(1), 88-95. Google Scholar

Saputra, Endra. (2018). Dampak Cryptocurrency Terhadap Perekonomian Indonesia. Seminar Nasional Royal (SENAR) 2018, 491 - 496. Google Scholar

Schwab-Pomerantz, C. (2019). Cryptocurrency. Network Journal. Google Scholar

Severyn, Aliaksei, Moschitti, Alessandro, Uryupina, Olga, Plank, Barbara, \& Filippova, Katja. (2014). Opinion Mining on YouTube. Proceedings of the 52nd Annual Meeting of the Association for Computational Linguistics (Volume 1: Long Papers), 1252-1261. https://doi.org/DOI: 10.3115/v1/P14-1118 Google Scholar

Shihab, Najwa. (2019). Hukum Islam Soal Uang Elektronik, KB dan Sebar Hoaks. Google Scholar

Sichinava, D. (2019). Cryptocurrency and Prospects of its Development. Ecoforum Journal. ecoforumjournal.ro. Google Scholar

Sindonews. (2021). Jokowi Apresiasi Pemuka Agama yang Berperan Ajak Umat Patuhi Prokes. Nasional.Okezone.Com. Google Scholar

Sokolova, Karina, \& Kefi, Hajer. (2020). No TitleInstagram and YouTube bloggers promote it, why should I buy? How credibility and parasocial interaction influence purchase intentions. Journal of Retailing and Consumer Services, 53(Maret), 1-9. https://doi.org/https://doi.org/10.1016/j.jretconser.2019.01.011 Google Scholar

Sulaeman, Arif Ramdan, Fazri, Anhar, \& Fairus, Fairus. (2020). Pemanfaatan Youtube sebagai media komunikasi dalam menyampaikan materi agama dan juga menjadi tempat dakwah baru bagi beberapa ustadz dan ulama. Communication, 11(1), 8193. Google Scholar

Suparman Fatwa. (2021). Abdul Somad.Hukum jual beli cryptocurrency di indodax. Indonesia. Google Scholar

Tarmizi, Erwandi. (n.d.). Hukum Bitcoin / Uang Digital. Google Scholar

Tektona, Rahmadi Indra, \& Safilia, Nadya Ulfa. (2020). Penggunaan Bitcoin Sebagai Alat Pembayaran Zakat Menurut Perspektif Hukum Islam. Adliya: Jurnal Hukum Dan Kemanusiaan, 14(1), 27-40. https://doi.org/DOI: 10.15575/adliya.v14i1.8542 Google Scholar 
Dini Turipanam Alamanda, Yusuf Murtadlo Hidayat, Ikin solikin, Budi S Purnomo

Turney, Peter D. (2002). Thumbs up or thumbs down? Semantic orientation applied to unsupervised classification of reviews. Proceedings of the 40th Annual Meeting on Association for Computational Linguistics, 417-424. Philadelphia. Google Scholar

Ustadz Abdul Somad Official. (2021). Bagaimana Hukum Investasi Digital Coin Ustadz? | Ustadz Abdul Somad, Lc., MA. Indonesia. Google Scholar

Wahid, Yenny. (2021). Uang Kripto, Halal atau Haram? Google Scholar

Widyastuti, Maria, \& Hermanto, Y. Budi. (2021). Cryptocurrency Analysis of Indonesian Market Education Facilities. International Journal of Economics, Business and Accounting Research (IJEBAR), 5(2), 534-546. Google Scholar

Yahya, Buya. (2018). Hukum Bisnis Bit Coin - Buya Yahya Menjawab. Google Scholar

Yussof, S. A., \& Al-Harthy, A. M. H. (2018). Cryptocurrency as an alternative currency in Malaysia: issues and challenges. ICR Journal. Google Scholar

\section{Copyright holder:}

Dini Turipanam Alamanda, Yusuf Murtadlo Hidayat, Ikin solikin, Budi S Purnomo (2021)

First publication right:

Syntax Literate: Jurnal Ilmiah Indonesia

This article is licensed under:

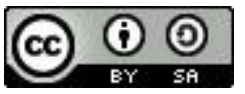

